\title{
Assessment of Morphometric and Genetic Variation in Three Freshwater Fish Species of the Genus Garra (Osteichthyes: Cyprinidae)
}

\author{
Arulraj DHINAKARAN ${ }^{1}$, Nabeel Mannalamkunnath ALIKUNHI ${ }^{1}$, Selvaraj \\ CHINNATHAMBI², Ramaiya SORNAM², Murugaiyan KALAISELVAM ${ }^{1}$ \\ Ramadoss RAJASEKARAN ${ }^{1}$, Subramanian MANIVANNAN ${ }^{3}$ \\ ${ }^{1}$ Annamalai University, Centre of Advanced Study in Marine Biology, Parangipettai, 608502, Tamil Nadu, India; smanmbbt@gmail.com \\ ${ }^{2}$ Manonmaniam Sundaranar University, Department of Biotechnology, Sri Paramaayani Centre \\ for Environmental Sciences, Awarkurichi, 627412, Tamil Nadu, India \\ ${ }^{3}$ Sathak College of Arts and Science, Department of Biotechnology, Mohammed, Sholinganallur, Chennai-119, Tamil Nadu, India
}

\begin{abstract}
The present study evaluated the patterns of morphometric and genetic variation using RAPD-PCR techniques for the first time on three species of Garra, viz. G. mullya, G. kalakadensis and G. gotyla stenorhynchus, collected from various river basins of South-India. The results of morphological analysis revealed that G. mullya and G. kalakadensis hold many similar characters compared to the other congener, G. gotyla stenorhynchus. However, the G. gotyla stenorhynchus fish species exhibited distinct variation in the morphological characters such as snout length, pre-nasal length, inter-nasal width, gap width, lower jaw to isthmus, head depth at pupil, dorsal fin length and disc width from the other two species of Garra. However, certain morphometric characters overlapped. Hence the RAPD finger printing was used to assess the levels of genetic variation in Garra spp. using RAPD-PCR technique. A total of 72 reliable fragments were detected using 10 Operon primers, ranging from 2600 molecular weight to 3100 . The shared RAPD fragments found in both $G$. mullya and $G$. kalakadensis with fixed frequencies were observed with all the investigated primers, implying their genetically closer relationship. However, the similarity index observed for G. gotyla stenorbynchus was less with the other two species specifying a genetically distant link. The present investigation thus contribute to the knowledge on morphological and genetic variation in these three Garra species.
\end{abstract}

Keywords: fresh water fishes, genetic variations, morphological changes, PCR, RAPD

\section{Introduction}

India is a land of 'biological paradise' which supports a great variety of flora and fauna with its diverse topography, climate and natural resource. The fresh water resources of Indian subcontinent are very rich but largely unexplored. An estimate states that there are 12 major rivers and 48 lesser rivers with a total catchment area of 277.6 million hectares (Ghosh and Ponniah, 2001). Out of the 2500 species of fishes, recognized in the Indian subcontinent, 930 are categorized as freshwater species (Jayaram, 1999) and account for $9.3 \%$ of global inland fish production (Ghosh and Ponniah, 2001). However, studies on freshwater fishes in the Indian subcontinent have been limited to scattered works on commercial fisheries and have been largely restricted to some of the major river systems. The fin fish population in many fresh water resources of the country still remains unexplored for their taxonomical delineation.

Taxonomy is the pioneering exploration of life on earth, which lays the foundation for the phylogenetic tree of life (Wilson, 2004). It provides requisite database for ecology and conservation science and makes access to the vast and still largely unexplored biodiversity to humanity (Wilson,
2004). For ichthyo-taxonomical studies, morphometric characters are generally being used in discriminating many fish species (Anyanwu and Ugwumba, 2003; Eyo 2002, 2003; Teugels, 1992). They are measurable features which are helpful for separating closely related genera, species and even populations within them (Cadrin, 2000).

The development of molecular techniques has received considerable attention for investigating the genetic diversity of the fishes. Advances in molecular techniques increased the availability of different DNA-based markers, which has become efficient tools in conservation genetic studies (Haig, 1998; Avise, 2004). Random amplified polymorphic DNA (RAPD) is a simple and straightforward PCR-based technique that enabled dramatic improvements in genetic diversity analysis within the past decade. This technique uses arbitrary primers for amplification of discrete regions of genome (Williams et al., 1990). RAPD markers have been used to evaluate the genetic diversity in numerous organisms and on fish populations belonging to the same family or genus (Ali et al., 2004; Cooper, 2000; Lockley and Bardsley, 2000).

The Garra Hamilton-Buchanan genus, belonging to the Garrinae subfamily, is widely distributed in fresh water basins of the world. 
According to Talwar and Jhingran (1991), this genus is represented by 21 species in the Indian subcontinent. Among this three closely related species, Garra mullya (Sykes, 1839), Garra kalakadensis (Rema Devi, 1993) and Garra gotyla stenorbynchus (Jerdon, 1849) are abundantly present in various fresh water basin of Tamil Nadu, South India. They slightly differ in their morphological features but certain characters overlap each other. The purpose of this study was to evaluate patterns of morphological and genetic variation in the primary range of the species, by examining banding pattern in several mitochondrial and nuclear genes, using RAPD-PCR techniques.

\section{Materials and methods}

Fish samples were collected from three geographically isolated river systems of the Western Ghats (Fig. 1). The Garra kalakadensis was collected from Kalakkad Mundandhurai Tiger Reserve (site 1); G. mullya from upstream of Hanumannadhi, one of the sub-basins of river Tamiraparani (site 2); G. gotyla stenorhynchus from Bhavani River near Mettupalayam (site 3). Fifteen individuals of each fish species were collected and preserved in $10 \%$ formalin (i.e., $4 \%$ formaldehyde solution) for morphometric studies and fresh fish samples were preserved in 90\% ethanol for isolation of genomic DNA. The morphometric measurements viz. standard length, preanal length, predorsal length, prepelvic length, prepectoral length, preoccipital

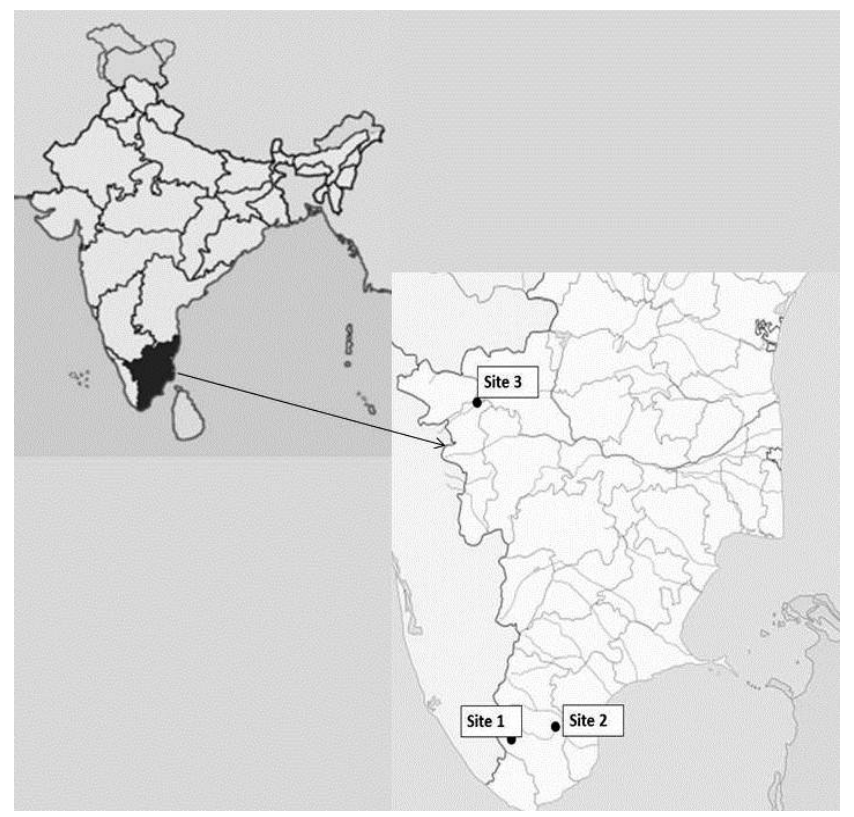

Fig. 1. The map showing various sites of fish collection for the experiment

length, snout to opercle distance, upper jaw length, snout length, prenasal length, orbit width, interorbital width, internasal width, head width, gape width, peduncle length, anal fin height, head depth at nostril, head depth at pupil, head depth at occiput, caudal peduncle depth, caudal fin length, dorsal fin height, pectoral fin length, pelvic fin length, pelvic axillary scale length, maxillary barbel length, rostral barbel length, distance $\mathrm{b} / \mathrm{w}$ pect fin and vent, distance $b / w$ pelc fin and vent and disc width distance $b / w$ vent and anal fin were taken. They were examined using correlation matrix in PCA and cluster analysis by the PAST software.

The total genomic DNA was extracted from muscle tissue following standard Phenol-Chloroform protocol (Sambrook et al., 1989). The quantification of DNA was done by UV spectrophotometer analysis. The quantity of DNA was measured by obtaining the absorbance reading at $260 \mathrm{~nm}$ and the purity of DNA was checked by calculating the ratio of absorbance readings at $260 \mathrm{~nm}$ and $280 \mathrm{~nm}$. After isolation, the DNA samples were taken out and mix with $7 \mu \mathrm{l}$ Bromophenol blue (sample loading dye) and a $15 \mu$ l of mixed DNA product was loaded in 1.5 $\%$ Agarose gel $(50 \mathrm{ml})$ containing Ethidium bromide at the concentration of $20 \mu \mathrm{l}$ per $50 \mathrm{ml}$ of gel. The electrophoresis was carried out for 1 to 2 hours at 50 volts. After electrophoresis gel was placed in the UV transilluminator and bands were visualized and were photographed in gel documentation system.

For the RAPD analysis, the DNA extracts were subjected to PCR amplification with primers purchased from Operon Technologies, U.S.A. Ten different primers were tested on fish samples and four better responding were selected for further studies. The RAPD profile generated by each set of primer was scored for presence or absence of an amplification product using agarose gel. The presence of a band was scored as 1 and the absence of it as 0 . Cluster analysis were performed and dendrograms plotted based on pair wise genetic distance estimated using the unweighed pair group method with arithmetic mean (UPGMA) based on Nei (1978).

\section{Results and discussion}

Morphometric measurement values obtained for the three species of Garra are shown in the Tab. 1. Garra mullya and G. kalakadensis are similar regarding morphological characters comparing to other congener, G. gotyla stenorhynchus. G. gotyla stenorhynchus exhibited distinct variation in the morphological character such as snout length, pre-nasal length, inter-nasal width, gap width, lower jaw to isthmus, head depth at pupil, dorsal fin length and disc width. The principale components analysis revealed that G. mullya and G. kalakadensis are more similar species than G. gotyla stenorbynchus (Fig. 2). The cluster analysis also exhibited a similar trend with G. gotyla stenorbynchus, distinguishable from the other two Garra species, G. mullya and G. kalakadensis. (Fig. 3). The morphometric results are insignificant to support the established genetic structure of the population that often leads to taxonomic uncertainty (Daniel, 1997; Ponnian and Gopalakrishnana, 2000; Garg et al., 2009b). The investigation was further extended to analyze the genetic variation. 
Tab. 1 . The proportional values of morphometric measurements of the three species

\begin{tabular}{|c|c|c|c|c|}
\hline No. & $\begin{array}{l}\text { Morphometric } \\
\text { measurements }\end{array}$ & $\begin{array}{c}G . \\
\text { mullya }\end{array}$ & $\begin{array}{c}G . \\
\text { kalakadensis }\end{array}$ & $\begin{array}{c}\text { G. gotyla } \\
\text { stenorbynchus }\end{array}$ \\
\hline 1 & Standard length & 527.245 & 666.54 & 878.455 \\
\hline 2 & $\begin{array}{l}\text { Snout to } \\
\text { urocentrum }\end{array}$ & 499.593 & 643.08 & 817.7092 \\
\hline 3 & Pre-anal length & 413.107 & 532.59 & 673.5358 \\
\hline 4 & $\begin{array}{l}\text { Pre-dorsal } \\
\text { length }\end{array}$ & 267.896 & 533.235 & 426.8375 \\
\hline 5 & $\begin{array}{l}\text { Pre-pelvic } \\
\text { length }\end{array}$ & 278.871 & 520.56 & 464.5125 \\
\hline 6 & $\begin{array}{l}\text { Pre-pectoral } \\
\text { length }\end{array}$ & 117.579 & 158.22 & 204.8717 \\
\hline 7 & $\begin{array}{l}\text { Pre-occipital } \\
\text { length }\end{array}$ & 129.907 & 152.205 & 205.195 \\
\hline 8 & Snout to opercle & 99.325 & 94.5 & 169.2817 \\
\hline 9 & $\begin{array}{l}\text { Upper jaw } \\
\text { length }\end{array}$ & 66 & 64.515 & 90.6 \\
\hline 10 & Snout length & 81.392 & 94.56 & 129.0333 \\
\hline 11 & Pre-nasal length & 53.368 & 64.845 & 75.79667 \\
\hline 12 & Orbit width & 39.348 & 43.035 & 53.21 \\
\hline 13 & $\begin{array}{l}\text { Inter orbital } \\
\text { width }\end{array}$ & 72.788 & 82.365 & 112.4533 \\
\hline 14 & $\begin{array}{l}\text { Inter nasal } \\
\text { width }\end{array}$ & 47.608 & 56.22 & 78.13667 \\
\hline 15 & Head width & 116.088 & 144.72 & 173.38 \\
\hline 16 & Gape width & 75.2 & 91.44 & 115.1833 \\
\hline 17 & Peduncle length & 74.134 & 82.125 & 134.6658 \\
\hline 18 & Anal fin height & 115.392 & 137.235 & 189 \\
\hline 19 & $\begin{array}{l}\text { Head depth } \\
\text { at nostril }\end{array}$ & 65.972 & 76.71 & 126.2533 \\
\hline 20 & $\begin{array}{l}\text { Head depth } \\
\text { at pupil }\end{array}$ & 84.472 & 95.085 & 144.0167 \\
\hline 21 & $\begin{array}{l}\text { Head depth } \\
\text { at occiput }\end{array}$ & 96.912 & 112.74 & 157.71 \\
\hline 22 & Peduncle depth & 69.396 & 82.515 & 127.1275 \\
\hline 23 & $\begin{array}{l}\text { Caudal fin } \\
\text { length }\end{array}$ & 169.384 & 194.445 & 329.7167 \\
\hline 24 & $\begin{array}{l}\text { Dorsal fin } \\
\text { height }\end{array}$ & 141.612 & 162.675 & 241.06 \\
\hline 25 & $\begin{array}{l}\text { Pectoral fin } \\
\text { length }\end{array}$ & 151.052 & 173.955 & 223.7933 \\
\hline 26 & Pelvic fin length & 129.472 & 148.2 & 196.4667 \\
\hline 27 & $\begin{array}{l}\text { Pelvic axillary } \\
\text { scale length }\end{array}$ & 42.984 & 36 & 82.21 \\
\hline 28 & $\begin{array}{l}\text { Maxillary } \\
\text { barbell length }\end{array}$ & 25.084 & 15.12 & 28.74333 \\
\hline 29 & $\begin{array}{l}\text { Rostral barbel } \\
\text { length }\end{array}$ & 36.088 & 36 & 42.70667 \\
\hline 30 & $\begin{array}{l}\text { Distance } b / w \\
\text { pect fin/vent }\end{array}$ & 270.648 & 325.545 & 428.71 \\
\hline 31 & $\begin{array}{l}\text { Distance } b / w \\
\text { pelc fin/vent }\end{array}$ & 111.704 & 124.905 & 156.3933 \\
\hline 32 & Disc width & 61.024 & 57.195 & 70.85667 \\
\hline 33 & $\begin{array}{l}\text { Distance } b / w \\
\text { vent/anal fin }\end{array}$ & 42.708 & 47.055 & 70.88 \\
\hline
\end{tabular}

Tab. 2. Nucleotide sequences of RAPD primers (OPA-01-10) showing amplification status with the three fish species (best performing primers are in bold)

\begin{tabular}{|c|c|c|c|c|}
\hline $\begin{array}{l}\frac{0}{0} \\
0 \\
\dot{0} \\
\Xi \\
\Xi \\
0\end{array}$ & 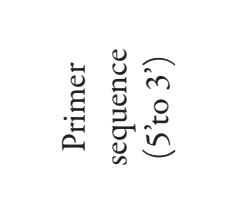 & 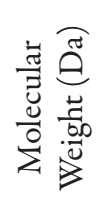 & 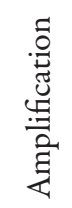 & 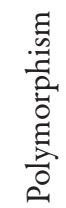 \\
\hline OPA-01 & CAGGCCCTTC & 2985 & ND & ND \\
\hline OPA-02 & TGCCGAGCTG & 3035 & + & ++ \\
\hline OPA-03 & AGTCAGCCAC & 2987 & + & ++ \\
\hline OPA- 04 & AATCGGGCTG & 2964 & ND & ND \\
\hline OPA- 05 & AGGGGTCTTG & 3048 & ND & ND \\
\hline OPA-06 & GGTCCCTGAC & 3056 & + & ++ \\
\hline OPA-07 & GAAACGGGTG & 3108 & + & ++ \\
\hline OPA-08 & GTGACGTAGG & 3012 & ND & ND \\
\hline OPA-09 & GGGTAACGCC & 2978 & ND & ND \\
\hline OPA-10 & GTGATCGCAG & 2992 & ND & ND \\
\hline
\end{tabular}

ND: Not Detected; +: Amplification present; ++: Polymorphic Bands Present; -: No Polymorphic Bands Present; ${ }^{* *}$ :Selected primers for this study

Tab. 3. The pair wise comparison of Nei's genetic identity of three species of Garra

\begin{tabular}{cccc}
\hline Species & G. mullya & $\begin{array}{c}G . \\
\text { kalakadensis }\end{array}$ & $\begin{array}{c}\text { G. gotyla } \\
\text { stenorhynchus }\end{array}$ \\
\hline G. mullya & ${ }^{* * * *}$ & 0.2369 & 0.3544 \\
G. kalakadensis & 0.2369 & ${ }^{* * *}$ & 0.5912 \\
G. gotyla stenorhynchus & 0.3544 & 0.5912 & ${ }^{* * * *}$ \\
\hline
\end{tabular}

The isolation of high quality DNA is essential for many molecular biology applications using polymerase chain reaction (Chakraborty et al., 2008). This systematics realm of methods offers new suites of characters for analyzing the relationship among the fishes (Hillis, et al., 1996; Carvalho and Pitcher, 1995). In the present study, an optimum quantity of DNA was found in all the extracts of the fish

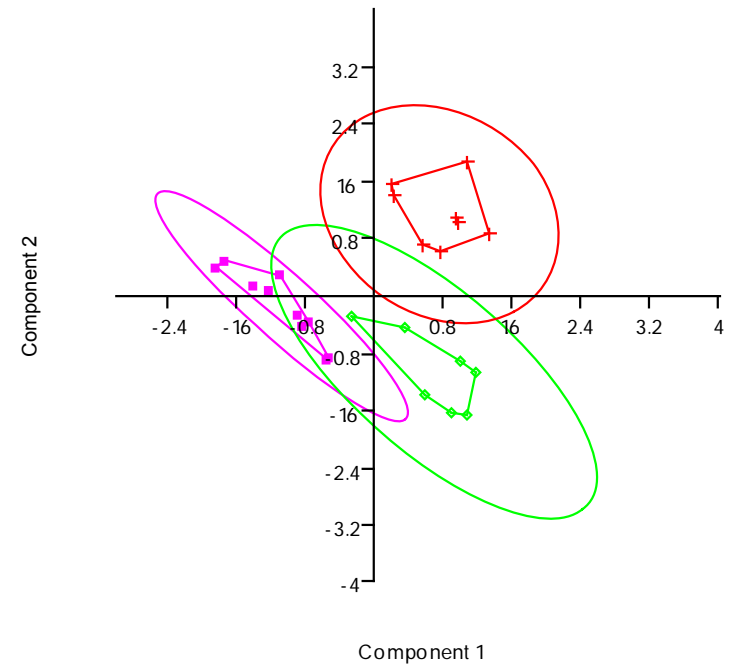

Fig. 2. The PCA scatter diagram showing the variation of the three Garra species (red for Garra mullya, green for Garra kalakadensis and pink for Garra gotyla stenorhynchus) 


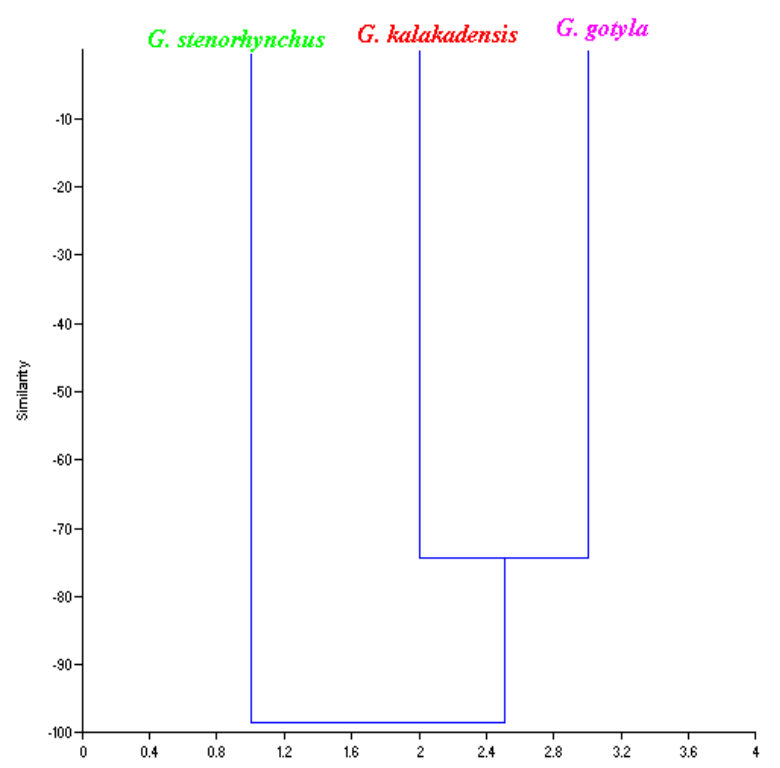

Fig. 3. Cluster analysis of three Garra species

species with various primers. A total of 72 reliable fragments were detected and observed using 10 Operon primers ranging from 2600 molecular weight to 3100 . Thus 4 of the better responded primers viz. OPA-02, OPA-03, OPA-06 and OPA-7 were used for further studies (Tab. 2 ). Each of the random primers produced distinct polymorphic banding patterns at all of the fishes (Fig. 4). The
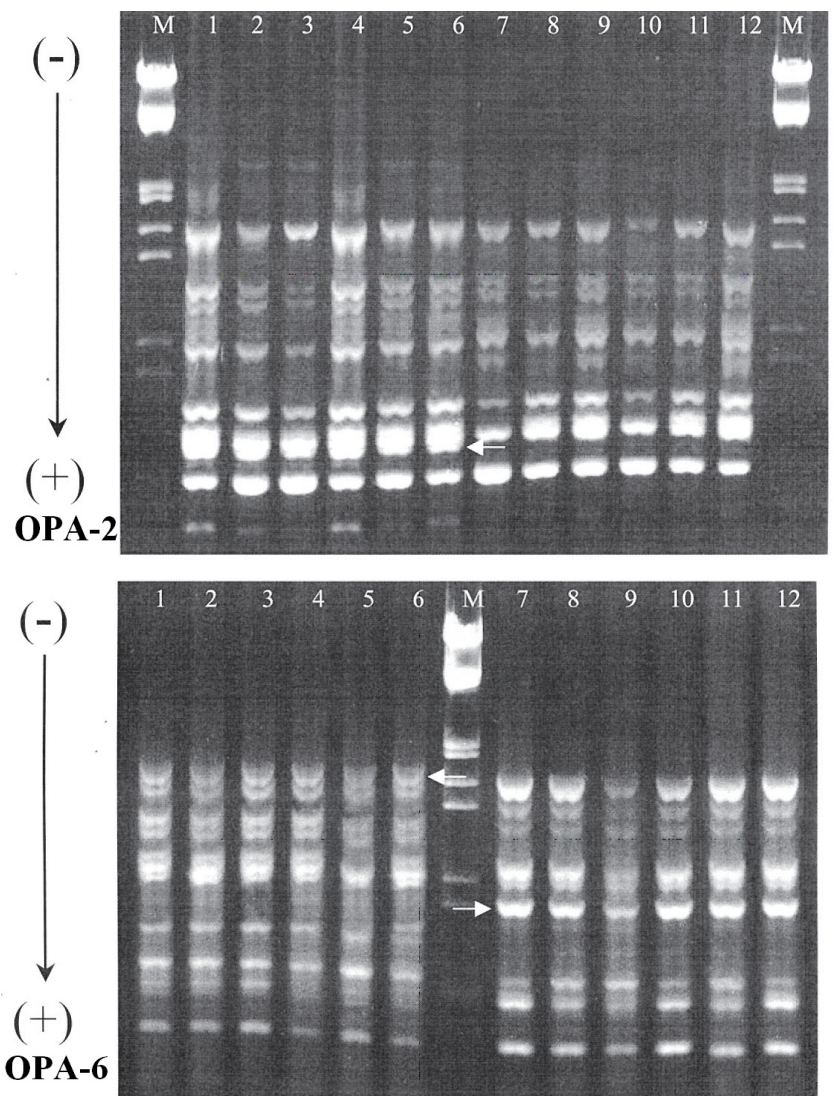

OPA- 6 primers produced the maximum number of amplified products. Reproducible polymorphic bands from the RAPD analysis were screened qualitatively for presence or absence in each sample. The shared RAPD fragments found in both G. mullya and G. kalakadensis with fixed frequencies were also observed in all investigated primers, implying their genetically close relationships. The pair wise comparison of genetic distance of three species revealed that $G$. mullya are more similar, considering the G. kalakadensis index, with less genetic distance (Tab. 4). However, G. gotyla stenorhynchus was showing higher genetic distances with two species, which was higher with $G$. kalakadensis. A similar observation was found with cluster analysis, in which G. gotyla stenorhynchus was separated from the other two species of Garra (Fig. 5). Hence, the present investigation revealed the taxonomical relation between three Garra species, which will contribute much to the least studied fresh water fishes of India.

Genetic approaches offer powerful tools for examining the current status of populations, for understanding the population changes for its conservation (Belfiore and Anderson, 2001). RAPD technique is one of the most frequently used molecular methods for taxonomic and systematic analyses of various organisms (Garg et al., 2009a; 2010). The present study evaluated morphometric characters and patterns of genetic variation in three Garra species. Both the morphological and genetic analysis revealed that G. mullya and G. kalakadensis had many similar char-
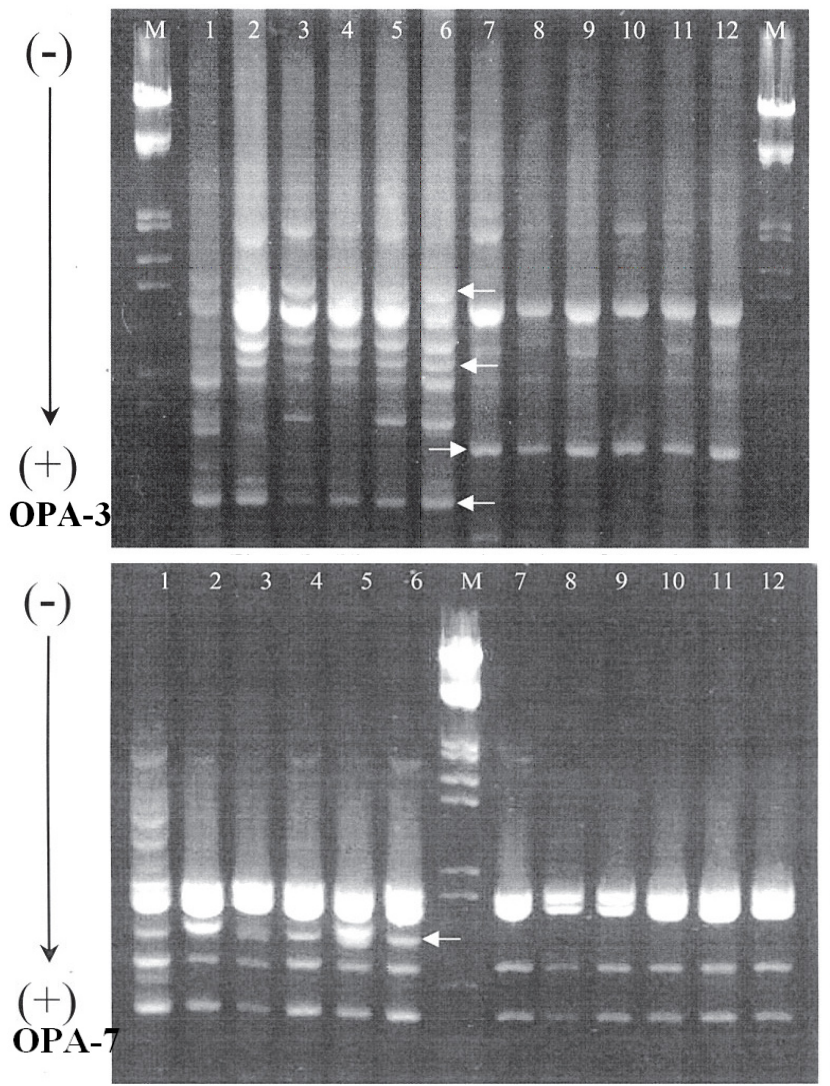

Fig. 4. RAPD pattern with various primers tested for the three species of Garra. Lane no. (1-4) different individuals of Garra mullya, Lane no. 5-8 different individuals of Garra Kalakadensis and Lane no. 9-12 different individuals of Garra gotyla stenorhynchus. Arrows indicate the species specific markers 
16

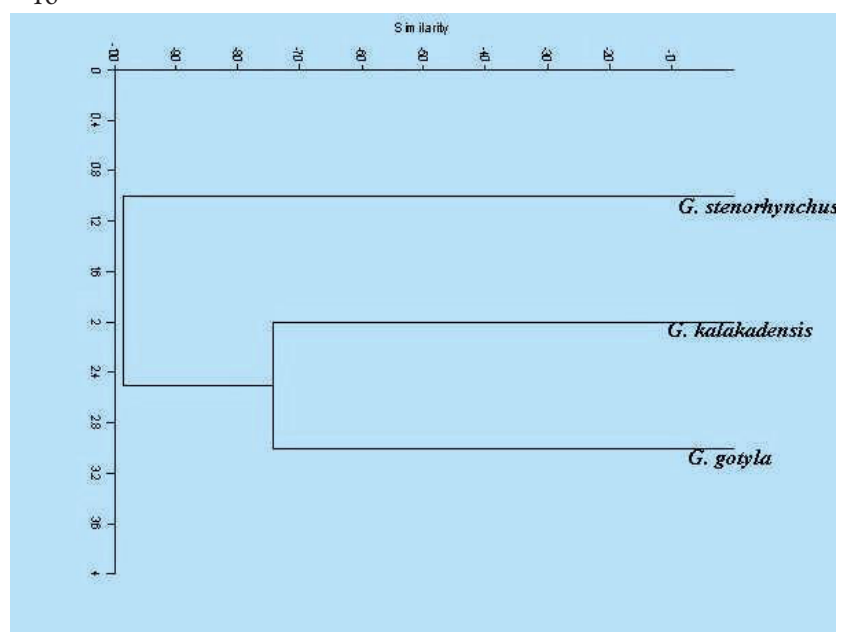

Fig. 5. The cluster analysis showing the genetic relation of the three species of Garra

acters, whereas G. gotyla stenorhynchus exhibited distinct variations. The present structure of genetic diversity is the invisible dimension of biological diversity, being the result of the evolutionary history of the species exposed to natural selection pressures in variable environmental conditions. Natural selection at the local level is an evolutionary force opposed to gene flow. The combination of the two forces creates a powerful mechanism for maintaining within-species diversity (Edward et al., 2002).

\section{Conclusions}

The present investigation revealed the morphometric and genetic variation of three Garra species. The results of morphological approach revealed that G. mullya and $G$. kalakadensis are more similar in comparison to the other congener, G. gotyla stenorbynchus. The latter exhibits distinct variation both in the morphological character and genetic fragments. The present investigation contribution to the knowledge on morphological and genetic variation to the Garra species. However, much specific molecular biomarkers are required for understanding the taxonomical relations of many other species of this group, which are widely distributed in various fresh water basins of India.

\section{Acknowledgments}

The authors are thankful to the authorities of Annamalai University, Manonmaniam Sundaranar University and Mohammed, Sathak College of Arts and Science for providing facilities.

\section{References}

Ali BA, Huang TH, Qin Da N, Wang XM (2004). A review of random amplified polymorphic DNA (RAPD) markers in fish research. Rev Fish Biol Fish 14:443-453.

Avise JC (2004). Molecular Markers, Natural History and Evolution. $2^{\text {nd }}$ ed. Sinauer Associates, Sunderland.

Belfiore NM, Anderson SL (2001). Effects of contaminants on genetic patterns in aquatic organisms: A review. Mutat Res
489:97-122.

Carvalho GR, Pitcher TJ (1995). Molecular genetics in fisheries. Chapman and Hall, New York.

Chakraborty S, Vijayan K, Nair CV, Santra SC, Bhattacharya T (2008). Isolation and characterization of high quality DNA from marine benthic macroalgae. J Environ Biol 29:907910.

Cooper ML (2000) Random amplified polymorphic DNA analysis of southern brown bandicoot (Isoodon obesulus) populations in Western Australia reveals genetic differentiation related to environmental variables. Mol Ecol 9:469-479.

Daniel RJ (1997).Taxonomic uncertainities and conservation of the Western Ghats. Curr Sci 73:169-170.

Edward S, Buckler IV, Jeffrey M (2002). Molecular diversity and applications to genomics. Cur Opi Pla Bio 5:107-111.

Garg RK, Sairkar P, Silawat N, Mehrotra NN (2009a). Genetic polymorphism of two populations of catfish Aorichthys seenghala (Sykes) using RAPD fingerprinting. Int J Int Zool 3:130-134.

Garg RK, Sairkar P, Silawat N, Vijay N, Batav N, Mehrotra NN (2009b). Genetic diversity between two populations of Heteropneustes fossilis (Blech) using RAPD profile. Int J Zool Res 4:171-177.

Ghosh SK, Ponniah AG (2001). Fresh Water Fish Habitat Science and Management in India. Aqu Ecosys Health Manag 4(4):367-380.

Haig SM (1998). Molecular contributions to conservation. Ecology 79:413-425.

Hills DM, Moritz C (1996). Molecular systematics Sinauer Assoc. Inc., Sunderland, USA.

Jayaram KC (1999). The freshwater fishes of the Indian region. Narendra Publishing house, New Delhi.

Lockley AK, Bardsley RG (2000). DNA-based methods for food authentication. Trends Food Sci Tech 11:67-77.

Nei M (1978). Estimation of average heterozygosity and genetic distance from a small number of individuals. Genetics 89:583-590.

Ponnian AG, Gopalakishnan A (2000). Cultivable, ornamental, sport and food fishes endamic to peninsula India with special reference to Western Ghats. In: Ponnian AG and Gopalakishnan A (Eds.). Endemic fish diversity of Western Ghats NBFGR-NATP Publication, National Bureaw of Fish Genetic Resources, Lucknow, India.

Sambrook J, Russell DW (1989). Molecular cloning. A laboratory manual. Cold Spring Harbor Laboratory Press, New York.

Talwar PK, Jhingaran AG (1991). Inland fishes of India and adjacent countries. Oxford and IBH, New Delhi

Williams JGK, Kubelik AR, Livak KJ, Rafalski JA, Tingey SV (1990). DNA polymorphisms amplified by arbitrary primers are useful as genetic markers. Nucleic Acids Res 18:6531-6535.

Wilson EO (2004). Taxonomy as a fundamental discipline. Phil Trans Royal Soc London B 359:739. 